Novialita Angga Wiratama

\title{
MENINGKATKAN KETERAMPILAN MENULIS NARASI MELALUI MEDIA AUDIO REKAMAN BERITA RADIO PADA SISWA KELAS VB SDN KADEMANGAN 01 KABUPATEN BLITAR
}

\author{
Novialita Angga Wiratama \\ Universitas PGRI Ronggolawe \\ Prodi Pendidikan Guru Sekolah Dasar \\ novialita3@ymail.com
}

\begin{abstract}
Abstrak: Penelitian ini bertujuan untuk (1) Mendeskripsikan keterampilan menulis narasi kelas VB SDN Kademangan 01 dengan bantuan media audio berupa rekaman berita radio (2) Mendeskripsikan peningkatan keterampilan menulis narasi siswa kelas VB di SDN Kademangan 01 Kabupaten Blitar dengan bantuan media audio berupa rekaman berita radio. Data yang diperoleh berupa hasil tes, lembar observasi, wawancara dan dokumentasi dianalisis dengan teknik deskriptif kualitatif. Hasil penelitian yang telah dilaksanakan dengan penerapan media audio berupa rekaman berita radio diperoleh peningkatan keterampilan menulis narasi pada siswa di kelas VB.
\end{abstract}

Kata Kunci: menulis narasi, media audio rekaman berita, hasil belajar.

Menguasai keterampilan menulis dalam dunia bahasa dapat membantu siswa berlatih berpikir, mengungkapkan gagasan, dan memecahkan masalah. Menulis adalah suatu bentuk berpikir, yang juga merupakan alat untuk membuat orang lain (pembaca) berpikir. Melalui menulis, siswa mampu menyatakan berbagai ilmu atau pengetahuan yang dimiliki dalam sebuah tulisan, baik dalam bentuk, artikel, laporan ilmiah, berita, cerpen, puisi, dan sebagainya. Sebagai suatu keterampilan berbahasa, menulis merupakan kegiatan yang kompleks karena dalam kegiatan menulis seorang penulis dituntut untuk dapat menyususn dan mengorganisasikan isi tulisan serta menuangkannya dalam susunan ragam bahasa tulis dan aturan penulisan lainnya. Seorang penulis tidak saja harus menguasai prinsip-prinsip menulis, berwawasan dan berpengetahuan luas, menguasai kaidah-kaidah bahasa, terampil menyusun kalimat dalam sebuah paragraf, tetapi juga harus mengetahui prinsip-prinsip berpikir. Menulis dapat meningkatkan kecerdasan, mengembangkan daya inisatif dan kreatifitas, menumbuhkan keberanian, serta merangsang kemampuan dan kemauan mengumpulkan informasi.

Penulis harus memiliki berbagai informasi tentang apa yang akan ditulis. Informasi tersebut dapat diperoleh dari membaca dan mendengarkan dari berbagai sumber dan media informasi. Menulis merupakan sebuah proses, yaitu menulis merupakan serangkaian aktivitas yang terjadi dan melibatkan beberapa tahap antara lain, tahap prapenulisan (persiapan), penulisan (pengembangan isi karangan), dan pascapenulisan (telaah dan revisi atau penyempurnaan tulisan). Adapun penjelasannya adalah sebagai berikut. Menurut Gie (2002:9) menjelaskan bahwa kata mengarang dan menulis adalah kata sepadan yang memiliki arti yang sama. Dengan demikian, menulis, tulisan, penulis dan tulis-menulis adalah sama seperti pengertian mengarang, karangan, pengarang dan karang-mengarang

Menulis dapat didefinisikan sebagai suatu kegiatan penyampaian pesan dengan menggunakan bahasa tulis sebagai alat atau medianya (Suparno, 2007: 1.3). Sejalan dengan pendapat Mulyati (2009:1.13), "menulis merupakan kegiatan yang produktifdengan menggunakan tulisan". Dalam kegiatan menulis ini, maka penulis harus terampil memanfaatkan grafologi, struktur bahasa, dan kosakata. Menulis disebut sebagai kegiatan produktif karena kegiatan menulis menghasilkan tulisan, dan disebut sebagai kegiatan. Penulis harus memiliki berbagai informasi tentang apa yang akan ditulis. Informasi tersebut dapat diperoleh dari membaca ataupun mendengarkan berbagai sumber dan media informasi.

Salah satu jenis menulis yang dipelajari di SD adalah menulis karangan narasi. Istilah narasi atau sering disebut naratif berasal dari kata bahasa Inggris yaitu narration (cerita) dan narrative (yang menceritakan). Suparno (2007:1.11) menyatakan bahwa, narasi adalah ragam wacana yang menceritakan proses kejadian suatu peristiwa". Karangan narasi merupakan karangan yang menyajikan serangkaian peristiwa atau kejadian menurut urutan terjadinya dengan maksud memberikan arti kepada setiap kejadian sehingga pembaca dapat menarik hikmah dari kejadian tersebut. Unsur penting yang ada dalam karangan 
narasi adalah unsur perbuatan dan waktu. Keduanya terjalin dalam satu keutuhan tempat dan waktu. Ciriciri karangan narasi adalah sebagai berikut.

- Berupa cerita tentang peristiwa atau pengalaman penulis.

- Kejadian atau peristiwa yang disampaikan berupa peristiwa yang benar-benar terjadi, dapat berupa semata-mata imajinasi atau gabungan keduanya.

- Berdasarkan konfiks, karena tanpa konfiks biasanya narasi tidak menarik.

- Memiliki nilai estetika.

- Menekankan susunan secara kronologis.

Narasi dapat berisi fakta atau fiksi. Contoh narasi yang berisi fakta misalnya biografi, autobiografi, atau kisah pengalaman. Contoh narasi yang berupa fiksi misalnya novel, cerpen, cerbung, ataupun cergam. Dalam menyusun karangan narasi ada beberapa langkah, antara lain sebagai berikut.

- Menentukan tema dan amanat yang akan disampaikan.

- Menetapkan sasaran pembaca.

- Rancang peristiwa-peristiwa utama yang akan ditampilkan dalam bentuk kerangka karangan.

- Bagi peristiwa utama itu ke dalam bagian awal, perkembangan, dan akhir cerita.

- Membuat perincian peristiwa-peristiwa utama ke dalam detail-detail peristiwa sebagai pendukung cerita.

- Susun tokoh dan perwatakan, latar, dan sudut pandang.

Berdasarkan langkah-langkah di atas, awal narasi biasanya berisi pengantar yaitu memperkenalkan suasana dan tokoh. Bagian awal harus dibuat menarik agar dapat mengikat pembaca. Bagian tengah merupakan bagian yang memunculkan suatu konflik. Konflik lalu diarahkan menuju klimaks cerita. Setelah konfik timbul dan mencapai klimaks, secara berangsur-angsur cerita akan mereda. Akhir cerita yang mereda ini memiliki cara pengungkapan bermacam-macam. Ada yang menceritakannya dengan panjang, ada yang singkat, ada pula yang berusaha menggantungkan akhir cerita dengan mempersilakan pembaca untuk menebaknya sendiri.

Mengarang merupakan sebuah kegiatan menyampaikan ide, pikiran, pengetahuan ataupun perasaannya melalui bahasa tulis yang disusun dalam bentuk karya tulis seperti karangan, puisi dan cerita. Beberapa tahapan menulis adalah.

1) Tahap prapenulisan

Tahap ini merupakan tahap persiapan menulis. Tahap ini merupakan tahap mencari, menemukan, dan mengingat kembali pengetahuan atau pengalaman yang diperoleh dan diperlukan penulis. Tujuannya untuk mengembangkan isi dan mencari kemungkinan-kemungkinan lain dalam menulis sehingga tulisan tersebut dapat tersaji dengan baik. Pada tahap prapenulisan ini terdapat beberapa aktivitas antara lain:

a) Menentukan topik

Topik merupakan persoalan atau permasalahan yang menjiwai seluruh karangan. Kesulitan dalam menentukan sebuah topik karangan yang dialami yaitu tidak memiliki ide sama sekali tentang topik yang menarik hati penulis. Namun kasus seperti ini jarang terjadi karena pada lazimnya seseorang yang akan menulis telah memiliki ide tentang tulisannya.

b) Memperhatikan sasaran karangan (pembaca)

Keberhasilan menulis dipengaruhi oleh ketepatan pemahaman menulis terhadap pembaca tulisannya. Kemampuan ini memungkinkan penulis untuk memilih informasi serta cara penyajian yang sesuai. Seorang penulis harus pandai-pandai melihat sasaran tulisannya (pembaca) karena apa yang disampaikan penulis belum tentu dipa hami oleh pembaca. Oleh sebab itu sebagai penulis yang baik harus membaca berulang-ulang karyanya atau meminta orang lain membaca tulisa penulis yang bertujuan untuk merevisi jika ada kesalahan atau ketidakpahaman pembaca.

b) Mengumpulkan informasi pendukung

Menyampaikan informasi pendukung ini harus dilakukan agar tulisan menjadi lebih bermutu. Sebelum menulis perlu mencari, mengumpulkan, dan memilih informasi yang dapat mendukung, memperluas, memperdalam, dan memperkaya isi tulisan. Sumber yang diperoleh dapat berupa bacaan, pengamatan, wawancara, pengetahuan, dan pengalaman sendiri atau orang lain. Pengumpulan informasi 
Novialita Angga Wiratama

ini dapat dilakukan sebelum, sewaktu atau sesudah penulisan terjadi. Namun akan lebih baik jika informasi yang relevan telah terkumpul secukupnya sebelum menulis.

c) Mengorganisasikan ide dan informasi

Langkah terakhir dalam tahap prapenulisan adalah mengorganisasikan atau menata ide-ide karangan agar menjadi saling berhubungan, runtut, dan padu. Dalam menyusun ide perlu dipilah-pilah ide dan informasi yang terkait dengan karangan. Jika hal tersebut sudah dilakukan maka penyusunan ide-ide dan informasi itu disebut kerangka karangan. Kerangka karangan dapat membantu penulis ketika mengembangkan suatu karangan.

2) Tahap penulisan

Dalam tahap prapenulisan telah dikumpulkan topik dan tujuan karangan, mengumpulkan informasi yang releann, dan membuat karangan. Jika hal tersebut sudah dilakukan maka tahap selanjutnya adalah tahap penulisan. Dalam hal ini yang harus dilakukan adalah mengembangkan ide yang terdapat dalam kerangka karangan dengan memanfaatkan bahan atau informasi yang sudah dipilih dan dikumpulkan.

3) Tahap pasca penulisan

Pada tahap ini terjadi proses penghalusan dan penyempurnaan dari karangan yang ditulis pada tahap penulisan. Pada tahap ini kegiatan yang dilakukan adalah proses penyuntingan dan perbaikan (revisi). Pada proses penyuntingan yang dilakukan adalah pemeriksaan dan perbaikan unsur mekanik karangan seperti ejaan, diksi, gaya bahasa, dan sebagainya. Sedangkan pada proses revisi yang dilakukan lebih mengarah pada pemeriksaan dan perbaikan isi karangan. Tujuan dilakukannya proses penyuntingan dan perbaikan adalah untuk menemukan atau memperoleh informasi tentang unsur-unsur karangan yang perlu disempurnakan. Kegiatan ini dapat dilakukan oleh orang lain atau penulisnya sendiri.

Berdasarkan hasil obserVBsi terhadap siswa kelas V SDN Kademangan 01 siswa kesulitan itu terdapat ketika mengawali menulis kalimat. Selain itu, siswa kesulitan menuangkan ide dalam bentuk tulisan, siswa kesulitan mengembangkan ide pokok menjadi paragraf. Menulis juga dianggap keterampilan yang mudah bagi siswa sehingga tidak memerlukan alat bantu untuk menunjang eskplorasi dan keterampilan siswa dalam pembelajaran menulis. Siswa kesulitan menuangkan ide dalam bentuk tulisan, siswa kurang bisa mengembangkan ide pokok menjadi paragraf. Selain itu, menulis dianggap keterampilan yang mudah bagi siswa sehingga tidak memerlukan alat bantu untuk menunjang eskplorasi dan keterampilan siswa dalam pembelajaran menulis. Proses pembelajaran keterampilan menulis yang dilakukan selama ini selama ini lebih difocuskan pada teori menulis yang didapatkan dari buku teks. Beberapa materi yang dipelajari siswa dalam keterampilan menulis adalah teori menulis, seperti menentukan tema, topik, kerangka karangan, memilih dan menentukan judul karangan, penyusunan kalimat, penyusunan paragraf. Dari beberapa teori yang dipelajari oleh siswa tersebut tidak banyak waktu yang disediakan untuk berlatih menulis dengan alasan alokasi waktu yang tersedia terbatas sehingga menulis hanya menjadi pekerjaan rumah yang keesokan harinya dikumpulkan tanpa adanya koreksi bersama di dalam kelas. Saat proses pembelajaran bahasa Indonesia ketika guru mengajar menulis, siswa langsung diminta untuk membaca materi tentang membuat karangan yang ada di dalam buku paket kelas V, kemudian siswa diminta untuk membuat karangan seperti yang ada dalam buku tersebut. Guru tidak menjelaskan karakteristik dan contoh karangan sebelumnya. Beberapa permasalahan lain yang dihadapi siswa dalam menulis adalah siswa tidak mengetahui tujuan dari menulis. Siswa menulis hanya karena ada tugas dari guru.

Melihat permasalahan yang dihadapi oleh siswa dalam menulis, tentunya dapat diatasi dengan menggunakan media pembelajaran yang menarik bagi siswa. Media yang menarik dan dapat membuat siswa aktif dalam pembelajaran adalah rekaman berita radio. Penggunaan media rekaman berita radio dapat membuat siswa lebih aktif dalam pembelajaran dan mempermudah dalam memahami isi berita sehingga siswa dapat membuat sebuah cerita narasi untuk mengasah keterampilan menulis. Berdasarkan hasil obserVBsi yang telah dilakukan di SDN Kademangan 01 pada kelas $\mathrm{V}$ pembelajaran bahasa Indonesia, dalam mengembangkan keterampilan menulis, siswa kebanyakan diberikan tugas mengarang bebas dengan tema ditentukan oleh guru. Pembelajaran menulis tidak menggunakan media pembelajaran sehingga siswa merasa bosan dengan tugas yang diberikan oleh guru. Dalam pembelajaranpun guru hanya terpancang pada buku teks, siswa mendengarkan penjelasan guru sambil melihat buku teks, 
kemudian siswa belajar menulis dari materi yang telah diberikan. Akibatnya siswa tidak menyukai pembelajaran menulis sehingga nilai keterampilan menulis siswa rendah.

Siswa kelas V SDN Kademangan 01 berjumlah 32 anak. Nilai kriteria ketuntasan minimal (KKM) yang ditetapkan sekolah 70. Dari jumlah seluruh siswa hanya 10 anak yang tuntas dalam pembelajaran bahasa Indonesia keteram-pilan menulis narasi. Hasil karangan siswa ditinjau dari isi tulisan dinilai kurang hidup karena tidak ada penataan yang apik dari isi karangan yang dibuat. Selain itu siswa kurang teliti dalam penggunaan ejaan, penggunaan huruf kapital dan tanda baca. Menghadapi permasalahan pembelajaran tersebut perlu adanya upaya untuk mengatasi dengan cara melatih keterampilan menulis siswa dengan tugas yang lain yaitu dengan menulis teks berita yang lebih sederhana dibandingkan dengan membuat karangan. Selain itu guru perlu menggunakan media pembelajaran supaya dapat menarik perhatian siswa yaitu menggunakan media rekaman berita dari radio sebagai media pembelajaran. Media merupakan alat yang digunakan guru untuk memperlancar jalan-nya pembelajaran sehingga dapat mencapai tujuan yang diharapkan.

Ada beberapa media pembelajaran yang dapat digunakan dalam proses pembelajaran, baik media sederhana, konvensional dan murah harganya, maupun media yang kompleks, rumit, modern, dan harganya sangat mahal. Media merupakan bagian yang tidak dapat terpisahkan dari proses pembelajaran. Fungsi media pembelajaran menurut para ahli diantaranya untuk menarik perhatian siswa. Selain itu fungsi media adalah sebagai alat bantu dalam pembelajaran dan sebagai media belajar yang digunakan oleh siswa. Beberapa fungsi media pembelajaran. Fungsi utama media pembelajaran pada dasarnya adalah sebagai penyampai pesan dalam pembelajaran. Fungsi utama media yaitu mengefektif-kan proses komunikasi pembelajaran sehingga tercapai tujuan yang diinginkan sehingga timbul perubahan tingkah laku siswa (Sardiman dkk, 2010: 36).

Berbagai kegiatan pembelajaran dilakukan oleh siswa setiap hari baik di dalam atau di luar kelas. Kegitan pembelajaran itu meliputi membaca, menjawab pertanyaan guru, mengerjakan tugas, ulangan, (tes) dan mendengarkan penjelasan dari guru. Dengan memanfaatkan media pembelajaran berupa media audio yang berasal dari radio, informasi dan materi pembelajaran dapat disampaikan dengan berbagai cara penyampaian dan rekaman suara manusia atau suara-suara lainnya untuk tujuan pembelajaran. Program siaran dapat direkam dan isi pesan dapat dipergunakan berulang kali dengan konsistensi, daya jangkauannya luas sehingga dapat menjangkau daerah terpencil, harganya terjangkau, dapat dipindahpindah, program dapat diedit sesuai yang dikehendaki, dapat menyajikan laporan-laporan seketika, dapat mengatasi batasan ruang dan waktu, dapat memberikan suasana alam nyata dengan berbagai teknik suara dan efek suara, dalam hal ini cocok untuk mengajarkan musik, sejarah, dan bahasa, dapat menyiarkan kejadian khusus, aktual dan peristiwa historis.

Manfaat dari penelitian ini adalah sebagai berikut. Manfaat bagi peneliti dapat digunakan sebagai pengalaman dalam menulis karya ilmiah, dan menambah wawasan pembelajaran menulis narasi di SD serta memberi motiVBsi peneliti untuk lebih tanggap terhadap berbagai permasalahan yang terjadi dalam kegiatan pembelajar-an, sehingga menjadi lebih kreatif, dan inovatif dalam menciptakan kegiatan pembelajaran yang bervariasi. Manfaat bagi siswa adalah membantu siswa untuk meningkatkan keterampilan dalam menulis narasi sehingga tulisan yang dibuat dapat memberikan informasi pada masyarakat. Bagi guru, penelitian ini dapat dijadikan bahan kajian untuk meningkatkan kinerja guru dalam pembelajaran dan dapat membantu sekolah dalam meningkatkan kualitas tujuan pembelajaran di lembaga tersebut. Sedangkan bagi sekolah adalah dapat membantu guru dalam mengembangkan pembelajaran bahasa Indonesia yang menyenangkan terutama dalam keterampilan menulis sehingga hasil pembelajaran lebih maksimal.

\section{METODE}

Penelitian ini merupakan jenis penelitian tindakan kelas dengan pendekat-an kualitatif deskriptif. Jenis penelitian yang digunakan ini menggunakan model Kemmis dan Taggart yaitu dimulai dari pratindakan, siklus I dan siklus II. Setiap siklus melalui empat tahapan, yang terdiri dari perencanaan, pelaksanaan tin-dakan, obserVBsi, dan refleksi sebagai prosedur baku penelitian. Penelitian ini dilaksanakan di SDN Kademangan 01 pada siswa kelas $\mathrm{V}$ pelajaran bahasa Indonesia keterampilan 
Novialita Angga Wiratama

menulis semester 2 tahun pelajaran 2016/2017 dengan jumlah siswa 33. Peneliti bertindak sebagai pelaksana tindakan yang dibantu guru kelas VB sebagai observer.

Data pelaksanaan pembelajaran menggunakan media audio berupa rekaman berita radio di kelas VB dilaksanakan pada siklus I dan siklus II. Data yang diambil meliputi proses dan produk. Untuk menganalisis tingkat keberhasilan pembelajaran atau persentase keberhasilan siswa setelah proses belajar mengajar dilaksanakan dengan cara mengukur kemampuan siswa dalam menulis narasi. Analisis diawali dengan pengumpulan data dari hasil observasi, wawancara, tes evaluasi dan dokumentasi. Data yang terkumpul disajikan dalam bentuk tabel dan uraian kemudian dibandingkan dengan berbagai informasi yang diperoleh. Dalam penelitian ini yang dibandingkan adalah data yang diperoleh dari hasil observasi dan wawancara. Pembandingan tersebut dilakukan untuk mendapatkan data yang akurat dan faktual. Kemudian dipadukan dengan data-data lain yang telah diperoleh. Langkah selanjutnya adalah menarik kesimpulan dari proses analisis yang sudah dilaksanakan sebagai hasil analisis.

Data hasil tes digunakan untuk mengetahui ketuntasan hasil belajar siswa. Penghitungan ketuntasan tersebut dihitung berdasarkan KKM di SDN Kademangan 01 pelajaran bahasa Indonesi yaitu 70. Ketuntasan belajar ada dua kategori yaitu secara perorangan dan secara klasikal. Ketuntasan belajar perseorangan dengan ketentuan siswa secara individu telah mencapai nilai minimal 70 atau $70 \%$ dalam menyelesaikan menulis narasi dengan baik. Ketuntasan belajar siswa klasikal dikatakan tuntas jika kelas terdapat $80 \%$ siswa yang telah mencapai daya serap lebih dari atau sama dengan 80 . Peningkatan hasil belajar siswa selama kegiatan pembelajaran dianalisis secara deskriptif dengan membandingkan rata-rata hasil tes yang telah diperoleh pada masing-masing siklus Arikunto (2002: 56).

\section{PAPARAN DATA DAN TEMUAN PENELITIAN Paparan Data Pratindakan}

Subjek dalam penelitian ini adalah siswa Kelas V SDN Kademangan 01 Tahun Ajaran 2016/2017 berjumlah 32 siswa. Kegiatan observasi dilaksanakan selama kegiatan belajar mengajar berlangsung peneliti mengamati seluruh kejadian yang ada di kelas. Dalam penelitian ini, peneliti bertindak sebagai observer, guru kelas bertindak sebagai pelaksana tindakan. Dalam observasi yang telah dilakukan peneliti di SDN Kademangan 01 Kabupaten Blitar, dalam proses pembelajaran bahasa Indonesia keterampilan menulis, guru kelas melaksanakan kegiatan sesuai dengan RPP yang telah disusun sebelumnya. Pada kegiatan awal, guru meng-ucapkan salam dan berdoa, melakukan presensi kehadiran siswa, kemudian guru melakukan kegiatan apersepsi, yaitu tanya jawab tentang pengalaman yang pernah dialami oleh siswa. Dalam pembelajaran keterampilan menulis siswa diberikan tugas mengarang dengan tema ditentukan oleh guru.

Hasil wawancara terhadap siswa diperoleh data sebagai berikut. Siswa kelas VB mayoritas menyukai pelajaran menulis baik menulis karangan, membuat pantun dan puisi, akan tetapi menulis karanganlah yang sering mereka lakukan. Menulis karangan biasanya dilakukan di rumah sebagai tugas dari guru dengan tema mengarang bebas. Tidak ada kriteria tertentu dalam menulis karangan yang ditugaskan guru. Pengumpulan karangan hasil karya siswa dilakukan dipertemuan selanjutnya pada pembelajaran Bahasa Indonesia. Hasil karya dikumpulkan pada guru tanpa adanya pembahasan bersama antara siswa dan guru kemudian dikembalikan seletah dikoreksi dan dinilai guru.

Hasil wawancara terhadap guru dalam membelajarkan keterampilan menulis adalah sebagai berikut. Sebelum pembelajaran dilakukan siswa dan guru melakukan tanya jawab seputar pengalaman menarik yang dialami. Guru membelajarkan siswa dalam menulis selama ini adalah memberikan kebebasan pada siswa untuk menulis karangan bertema pengalaman menarik. Siswa tidak diberikan arahan ketentuan-ketentuan khusus misalnya harus menggunakan ejaan dan tanda baca yang benar. Ketentuan-ketentuan khusus tersebut cukup diketahui guru untuk menilai pekerjaan siswa. Guru hanya memanfaatkan papan tulis sebagai media pembelajaran misalnya digunakan untuk mengartikan kata sulit sebelum siswa melakukan kegiatan menulis.

Berdasarkan hasil observasi yang telah peneliti lakukan pada tanggal 6 dan 7 Maret 2017, diketahui bahwa siswa masih kesulitan dalam menulis narasi, terutama dalam menetukan ide pokok dan mengembangakn ide pokok menjadi paragraph dan menyusun kalimat dengan baik. Selain itu siswa 
kurang teliti dalam menulis menggunakan kaidah EYD, pembelajaran bahasa Indonesia di SD masih berpusat pada guru dan tidak meng-gunakan media pembelajaran sebagai sumber belajar yang menunjang keberhasil-an pembelajaran. Selama pembelajaran berlangsung guru hanya menjelaskan, memberikan contoh dan menugaskan siswa, sebaliknya siswa hanya pasif mendengarkan penjelasan guru, mencatat penjelasan guru dan mengerjakan latihan yang telah ditugaskan oleh guru. Sebelum mengerjakan tugas siswa diberikan kesempatan untuk bertanya namun tidak ada yang bertanya. Untuk mengetahui kemampuan menulis siswa kelas $\mathrm{V}$ diambil dari dari hasil pembelajar-an bahasa Indonesia keterampilan menulis pratindakan.

Dari hasil keterampilan menulis siswa kelas VB ditemukan banyak siswa yang memperoleh nilai di bawah KKM yang telah ditentukan oleh SDN Kademangan 01 yaitu 70. Hasil keterampilan menulis berdasarkan data yang diperoleh 11 siswa dan dinyatakan tuntas dalam menulis sedangkan, 22 siswa mendapatkan nilai di bawah KKM sehingga belum dinyatakan tuntas dalam menulis. Siswa dinyatakan tuntas dalam pembelajaran keterampilan menulis jika mencapai nilai KKM yaitu 70. Apabila dipersentasekan siswa yang tuntas dalam menulis belajar adalah 33,3 \%sedangkan siswa belum tuntas 66,6\% dari jumlah siswa keseluruhan di kelas VB SDN Kademangan 01. Dapat disimpulkan, keterampilan menulis siswa kelas VB masih kurang, namun 11 siswa memiliki kemampuan menulis di atas KKM. Hal tersebut menunjukkan bahwa pada pratindakan siswa belum tuntas dalam keterampilan menulis secara klasikal. Persentase ketuntasan siswa yang memperoleh nilai di atas KKM hanya 33,3\% dari jumlah siswa, nilai tersebut lebih kecil dari persentase ketuntasan belajar yang harus dicapai yaitu $80 \%$.

Berdasarkan paparan data di atas dapat disimpulkan bahwa pembelajaran pratindakan masih memerlukan perbaikan agar keterampilan menulis siswa dapat meningkat. Sebagai upaya dalam meningkatkan keterampilan menulis siswa maka dilakukan perbaikan dalam pembelajaran keterampilan menulis menggunakan media audio berupa rekaman berita radio sebagai upaya untuk meningkatkan keterampilan menulis siswa yang akan dilaksanakan pada siklus I.

\section{Tindakan Siklus I}

Setelah melakukan refleksi pada pelaksanaan pembelajaran pratindakan yang dilaksanakan oleh guru kelas, maka peneliti perlu melakukan perbaikan pembelajaran menulis melalui media rekaman berita radio tentang pencurian. Siklus I pada penelitian ini dilaksanakan dalam dua kali pertemuan yaitu tanggal 13 dan 14 Maret 2017. Pelaksanaan pembelajaran menulis narasi menggunakan media rekaman berita siklus I ini melalui tahap perencanaan, pelaksanaan tindakan, pengamatan/ observasi dan refleksi.

Tahap perencanaan tindakan, peneliti melakukan analisis kurikulum untuk menentukan standar kompetensi. Langkah selanjutnya yang dilakukan peneliti adalah membuat RPP untuk menerapkan media audio rekaman berita radio. Tahap pelaksanaan tindakan siklus I peneliti bertindak sebagai guru dibantu oleh seorang observer yaitu guru kelas V. Tahap pelaksanaan tindakan dilaksanakan sesuai dengan RPP yang telah disusun sebelumnya. Materi pembelajaran menulis narasi, audio yang digunakan berupa rekaman berita pencurian. Selama pembelajaran setiap siswa memiliki kemampuan yang berbeda-beda. Pertemuan siklus I dilaksanakan selama dua kali pertemuan dengan alokasi waktu 2x35 menit. Adapun tahap-tahap pembelajaran sebagai berikut:

\section{Pertemuan 1}

Tahap pramenulis. Pembelajaran diawali dengan salam, do'a, presensi kehadiran siswa dan mengkondisikan siswa agar dapat mengikuti pembelajaran dengan baik. Kemudian melakukan kegiatan apersepsi dengan mengajukan beberapa pertanyaan pada siswa seputar peristiwa menyenangkan dan tidak menyenangkan. Selanjutnya guru memberikan informasi materi yang akan dipelajari siswa beserta tujuan mempelajari materi tersebut. Siswa dibagi menjadi beberapa kelompok setiap kelompok beranggotakan empat siswa. Pengelompokan siswa didasari atas tingkat kecerdasan siswa menurut hasil belajar keterampilan menulis siswa kelas V. Guru memberikan tugas kepada siswa untuk mencatat hal penting dari isi berita yang didengar. Setelah siswa duduk bersama anggota kelompok guru memutar berita yang telah disiapkan.

Tahap menulis, siswa mengerjakan LKS sesuai dengan petunjuk yang tersedia. Tugas yang terdapat di dalam LKS yaitu menulis narasi dengan mengembangkan berita yang telah didengarkan. Guru 
Novialita Angga Wiratama

membantu siswa menentukan ide pokok dari isi berita yang telah dicatat setiap kelompok kemudian siswa mengembangkan sendiri ide pokok menjadi paragraf narasi.. Tahap pascamenulis. Kegiatan yang dilakukan siswa adalah membaca kembali karangan yang dibuat dan membaca kembali dan meneliti hasil tulisan dan memperbaiki pekerjaan jika dianggap masih kurang sempurna masih terdapat kesalahan dalam menggunakan tanda baca ataupun ejaan. Setelah meneliti pekerjaan, kemudian dikumpulkan pada guru untuk dilakukan penilaian bersama. Hasil tulisan siswa dibagi secara acak pada teman untuk dilakukan penilaian. Guru membagikan lembar penilaian pada setiap kelompok. Siswa diberikan kesempatan untuk membaca petunjuk penilaian. Guru membimbing siswa untuk melakukan penilaian dan mengecek hasil penilaian yang dilakukan oleh siswa.

Kegiatan akhir pembelajaran, guru memberikan pemantapan materi pada siswa. Siswa bersama guru menyimpulkan hasil pembelajaran yang dilalui. Siswa mengungkapkan kesulitan dalam membuat paragraf narasi dan melakukan penilaian yang telah dilakukan. Siswa bersama-sama guru menyimpulkan hasil pembelajaran yang dilalui. Pembelajaran diakhiri dengan do'a dan salam penutup. Hasil penilaian karangan narasi yang dibuat oleh siswa kelas V SDN Kademanagan 01 Kabupaten Blitar selama melakukan kegiatan pembelajaran bahwa 21 siswa dan dinyatakan tuntas dalam menulis narasi sedangkan, 12 siswa mendapatkan nilai di bawah KKM sehingga belum dinyatakan tuntas dalam menulis. Siswa dinyatakan tuntas dalam pembelajaran keterampilan menulis jika mencapai nilai KKM yaitu 70. Apabila dipersentasekan siswa yang tuntas dalam menulis belajar adalah $63,6 \%$ sedangkan siswa belum tuntas $36,6 \%$ dari jumlah siswa keseluruhan di kelas. Kesimpulan, keterampilan menulis siswa kelas VB masih kurang, namun 21 siswa memiliki kemampuan menulis narasi di atas KKM. Hal tersebut menunjukkan bahwa pada pertemuan pertama siklus I siswa belum tuntas dalam keterampilan menulis secara klasikal. Persentase ketuntasan siswa yang memperoleh nilai di atas KKM hanya 63,6\% dari jumlah siswa, nilai tersebut lebih kecil dari persentase ketuntasan belajar yang harus dicapai yaitu $80 \%$.

Berdasarkan paparan data di atas dapat disimpulkan bahwa pembelajaran pertemuan I siklus I masih memerlukan perbaikan agar keterampilan menulis siswa dapat meningkat. Sebagai upaya dalam meningkatkan keterampilan menulis siswa maka dilakukan perbaikan dalam pembelajaran keterampilan menulis narasi pada pertemuan berikutnya. Selain menilai hasil keterampilan menulis paragraf narasi, guru juga menilai keterampilan siswa dalam melakukan.

Peneliti dan para observer melakukan pembahasan kegiatan pembelajaran yang telah dilaksanakan dalam pembelajaran. Berdasarkan pengamatan peneliti dan observer diperoleh data sebagai berikut. Tahap pramenulis. Selama kegiatan mendengarkan berita nampak beberapa siswa masih kesulitan dalam mencerna isi dari berita tersebut, sehingga perlu mengulasi memutar berita sebanyak $5 x$. Tahap menulis. Dalam tahap menulis siswa masih kesulitan dalam memulai menulis, kesulitan yang dialami oleh siswa diantaranya sulit membuat ide pokok yang akan dikembangkan.Oleh karena itu guru melalukan stimulus melalui bertanya apa isi dari berita kemudia siswa menjawab dengan menceritakan kejadian peristiwa. Setelah menulis peristiwa, siswa membuat ide pokok kemudian mengembagkan menjadi karangan narasi.. Siswa diberikan motiVBsi dan semangat berupa hadiah diakhir pembelajaran jika dapat dengan benar dalam menulis karangan narasi, selain itu guru juga memberikan bimbingan kepada setiap kelompok. Ada beberapa siswa dalam kelompok yang hanya bermain-main. Dalam mengembangkan ide pokok siswa tidak mengalami kesulitan namun kurang teliti dalam menggunakan huruf kapital. Dalam membuat kalimat hanya dilakukan oleh satu atau dua orang dalam satu kelompok, siswa masih menggantungkan diri pada teman yang dianggap pandai dan mampu.

Tahap pascamenulis. Siswa dalam satu kelompok membaca dan meneliti kembali hasil tulisan narasi yang telah dibuat sebelum ditukar untuk dinilai oleh teman. Siswa membaca dan meneliti kembali pekerjaan mereka dengan bersungguh-sungguh, meskipun ada beberapa siswa yang bermain sendiri di dalam satu kelompok. Setelah siswa meneliti pekerjaan, kegiatan selanjutnya adalah menukarkan pekerjaan antar kelompok untuk penilaian berdasarkan lembar penilaian antar teman yang telah dibagikan oleh guru.

Refleksi atas tindakan pertemuan I mencakup refleksi terhadap tahap pramenulis, menulis dan pascamenulis. Refleksi tahap pramenulis. Siswa masih kesulitan dalam mendengarkan isi dai berita yang didengarkan. Guru belum mengarahkan siswa secara maksimal dalam membangkitkan skemata siswa 
dalam menyimak isi berita. Tanya jawab dengan siswa perlu dilakukan lebih menyeluruh kepada semua siswa dikarenakan mungkin siswa yang diam saja takut untuk mengungkapkan jawaban atau pendapatnya.

Refleksi tahap menulis. Siswa kesulitan dalam menentukan ide pokok dan mengembangkannya menjadi paragraf. Pada tahap menulis belum nampak kerja sama dan pembagian tugas dalam mengerjakan LKS yang diberikan guru, beberapa siswa tidak terlibat aktif dalam diskusi kelompok mereka bermain-main dengan teman terhadap buah yang diberikan guru. Dalam pembelajaran selanjutnya diharapkan siswa dengan serius, bersungguh-sungguh dan tekun dalam proses pembelajaran menulis.

Refleksi tahap pascamenulis. Penilaian antar teman belum sepenuhnya terwujud karena saat melakukan penilaian hanya beberapa siswa saja yang terlibat dan masih terkesan asal-asalan dalam meneliti hasil pekerjaan kelompok. Hasil refleksi tersebut dipakai sebagai bahan untuk menyusun perbaikan pembelajaran yang akan dilaksanakan pada pembelajaran berikutnya. Hal-hal yang telah terlaksana dengan baik pada pertemuan sebelumnya dipertahankan sedangkan yang masih belum baik atau masih kurang akan dilaksanakan perbaikan pada pertemuan berikutnya.

\section{Pertemuan ke 2}

Pembelajaran tahap pramenulis. Pembelajaran diawali dengan salam, do'a, presensi kehadiran siswa dan mengkondisikan siswa agar dapat mengikuti pembelajaran dengan baik. Kemudian melakukan kegiatan apersepsi dengan mengajukan beberapa pertanyaan pada siswa seputar peristiwa kecelakaan. Selanjutnya guru memberikan informasi materi yang akan dipelajari siswa beserta tujuan mempelajari materi tersebut. Guru membagi siswa menjadi kelompok berpasangan kemudia memutarkan rekaman berita radio.

Tahap menulis, siswa mengerjakan LKS sesuai dengan petunjuk yang tersedia. Tugas yang terdapat di dalam LKS diantaranya menentukan ide pokok dari rekaman berita kemudian mengembangkannya menjadi paragraph sehingga menjadi karangan narasi yang padu. Tahap pascamenulis. Kegiatan yang dilakukan siswa dalam satu kelompok membaca kembali dan meneliti hasil tulisan. Setelah siswa meneliti pekerjaan, kegiatan selanjutnya adalah menukarkan pekerjaan antar kelompok untuk dilakukan penilaian.

Kegiatan akhir pembelajaran, siswa melakukan refleksi diri, mengungkapkan kesulitan yang dialami setelah melakukan pembelajaran sebagai upaya perbaikan proses pembelajaran berikutnya. Siswa mengisi angket sebagai refleksi dan mengungkapkan kesulitan dan kesenangan dalam membuat karangan narasi yang telah dilalui. Bersama-sama guru menyimpulkan hasil pembelajaran yang dilalui. Pembelajaran diakhiri dengan do'a dan salam penutup. Hasil penilaian tulisan narasi siswa kelas V SDN Kademangan 01 Kabupaten Blitar selama melakukan kegiatan pembelajaran adalah sebagai berikut siswa yang mendapatkan nilai di atas KKM adalah 23 siswa dan dinyatakan tuntas dalam menulis narasi sedangkan, 10 siswa mendapatkan nilai di bawah KKM sehingga belum dinyatakan tuntas dalam menulis. Siswa dinyatakan tuntas dalam pembelajaran keterampilan menulis jika mencapai nilai KKM yaitu 70. Apabila dipersentasekan siswa yang tuntas dalam menulis belajar adalah 69,6\%sedangkan siswa belum tuntas 30,3\% dari jumlah siswa keseluruhan di kelas V. Dapat disimpulkan, keterampilan menulis siswa kelas VB masih kurang, namun 23 siswa memiliki kemampuan menulis narasi di atas KKM. Hal tersebut menunjukkan bahwa pada pertemuan pertama siklus I siswa belum tuntas dalam keterampilan menulis secara klasikal. Persentase ketuntasan siswa yang memperoleh nilai di atas KKM hanya 69,6\%dari jumlah siswa, nilai tersebut lebih kecil dari persentase ketuntasan belajar yang harus dicapai yaitu $80 \%$.

Berdasarkan paparan data di atas dapat disimpulkan bahwa pembelajaran masih memerlukan perbaikan agar keterampilan menulis siswa dapat meningkat. Sebagai upaya dalam meningkatkan keterampilan menulis siswa maka dilakukan perbaikan dalam pembelajaran keterampilan menulis narasi pada siklus berikutnya.

\section{Narasi Hasil Tindakan Siklus 2}

Pelaksanaan pembelajaran menulis narasi menggunakan media rekaman berita siklus II ini melalui tahap perencanaan, pelaksanaan tindakan, pengamatan/ obserVBsi dan refleksi. Tahap perencanaan tindakan, peneliti melakukan pemetaan standar kompetensi dan kompetensi dasar. Langkah selanjutnya yang dilakukan peneliti adalah membuat RPP untuk menerapkan media audio rekaman berita radio. Materi 
Novialita Angga Wiratama

pembelajaran menulis narasi, audio yang digunakan berupa rekaman berita pencurian sepeda di taman bermain. Pelaksanaan tindakan siklus II dilaksanakan 2x pertemuan tanggal 20 dan 21 Maret 2017 di SDN Kademangan 01. Peneliti bertindak sebagai guru dibantu oleh observer guru mata pelajaran Bahasa Indonesia kelas VB

\section{Pertemuan 1}

Tahap pramenulis. Kegiatan pembelajaran diawali dengan guru memberikan salam, do'a bersama dan presensi kehadiran siswa. Apersepsi dilakukan guru dengan memberikan beberapa pertanyaan. Guru memberikan informasi materi yang akan dipelajari siswa beserta tujuan mempelajari materi tersebut. Siswa memperhatikan penjelasan guru tentang menulis paragraf narasi. Dalam membuat paragraf narasi siswa belajar mandiri tidak bersama anggota kelompoknya. Kegiatan selanjutnya guru membagikan LKS pada setiap kelompok. Kegiatan pembelajaran dimulai mendengarkan rekaman berita radio yang diputarkan oleh guru siswa.

Tahap menulis, siswa mengerjakan LKS sesuai dengan petunjuk yang tersedia. Siswa tidak mengalami kesulitan dalam membuat kalimat yang dikembangkan dari ide pokok menjadi paragrag karangan narasi. Tahap pascamenulis kegiatan yang dilakukan siswa dalam satu kelompok membaca kembali dan meneliti hasil tulisan kemudian ditukarkan dengan teman dari kelompok lain. Setelah dilakukan penilaian pekerjaan dikembalikan pada pemilik untuk dilakukan penelitian hasil penilaian teman. Setiap kelompok diberikan kesempatan untuk memberikan tanggapan, komentar dan sanggahan terhadap hasil penilaian teman. Secara bergantian siswa memberikan tanggapan dan sanggahan terhadap penilaian teman. Wakil kelompok dapat memberikan tanggapan dan sanggahan dengan tertib. Guru juga memberikan kesempatan bagi kelompok penilai untuk memberikan tanggapan terhadap komentar atau sanggahan dari pemilik pekerjaan yang dinilai. Setelah siswa memberikan komentar dan sanggahan kegiatan siswa selanjutnya adalah memperbaiki hasil tulisan narasi berdasarkan penilaian teman dan saran dari guru.

Kegiatan akhir pembelajaran, guru memberikan pemantapan materi pada siswa. Siswa menyimpulkan hasil pembelajaran yang dilalui. Siswa mengisi angket sebagai refleksi dan mengungkapkan kesulitan dalam membuat paragraf narasi yang telah dilalui. Pemberian reword pada siswa. Pembelajaran diakhiri dengan do'a bersama. Hasil penilaian tulisan narasi siswa kelas VB SDN Kademangan 01 selama melakukan kegiatan pembelajaran adalah sebagai berikut. Hasil penilaian tulisan narasi siswa kelas VB SDN Kademangan 01 selama melakukan kegiatan pembelajaran adalah sebagai berikut. bahwa siswa yang mendapatkan nilai di atas KKM adalah 25 siswa dan dinyatakan tuntas dalam menulis narasi, 8 siswa mendapatkan nilai di bawah KKM sehingga belum dinyatakan tuntas dalam menulis. Siswa dinyatakan tuntas dalam pembelajaran keterampilan menulis jika mencapai nilai KKM yaitu 70. Apabila dipersentasekan jumlah siswa tuntas dalam menulis belajar adalah $75,7 \%$, siswa belum tuntas $24,2 \%$ dari jumlah siswa keseluruhan di kelas.Dapat disimpulkan, keterampilan menulis siswa kelas VB masih kurang, namun 25 siswa memiliki kemampuan menulis narasi di atas KKM. Hal tersebut menunjukkan bahwa siswa belum tuntas dalam keterampilan menulis secara klasikal. Persentase ketuntasan siswa yang memperoleh nilai di atas KKM hanya $75,7 \%$ dari jumlah siswa. Nilai tersebut lebih kecil dari persentase ketuntasan belajar yang harus dicapai yaitu $80 \%$.

Selama pembelajaran berlangsung diperoleh data kegiatan siswa dalam kelompok terlihat kompak dalam meneliti hasil tulisan narasi yang telah mereka kerjakan. Setelah siswa meneliti pekerjaan, kegiatan selanjutnya adalah menukarkan pekerjaan antar kelompok untuk dilakukan penilaian berdasarkan lembar penilaian antar teman yang telah dibagikan oleh guru. Pekerjaan siswa ditukarkan pada teman yang mennarasikan objek yang sama. Misalnya kelompok yang mennarasikan wajik kletik ditukar dengan kelompok yang mennarasikan wajik kletik. Penukaran hasil pekerjaan siswa dilakukan dengan pola tersebut diharapkan siswa lebih mudah menilai pekerjaan teman sambil melakukan refleksi diri terhadap pekerjaannya. Sebelum melakukan penilaian siswa telebih dahulu mengisi identitas penilai dan yang dinilai selanjutnya membaca petunjuk penilaian.

Siswa dapat menemukan ide dengan mudah. Masing-masing kelompok para siswa terlihat serius dan antusias. Secara bersama-sama mereka bergantian melakukan menulis karangan narasi dan memberikan saran penulisan. Tahap menulis siswa bersama kelompok sudah bisa menulis tanpa 
mimbingan guru namun maih ada beberapa siswa yang memerlukan bantuan guru. Dalam membuat kalimat para siswa tidak mengalami kesulitan, sudah ada pembagian tugas secara bergantian menyusun paragraph tidak ada siswa menggantungkan diri pada teman yang dianggap pandai dan mampu. Ada beberapa siswa kurang teliti dalam menggunakan huruf capital namun sudah diingatkan temannya dalam satu kelompok.

Tahap pascamenulis. Siswa dalam satu kelompok membaca dan meneliti kembali hasil tulisan narasi sebelum ditukar untuk dinilai oleh teman. Siswa membaca dan meneliti kembali pekerjaan mereka dengan bersungguh-sungguh, meskipun ada beberapa siswa yang bermain sendiri di dalam satu kelompok. Selanjutnya menukarkan pekerjaan antar kelompok untuk dilakukan penilaian.

Refleksi atas tindakan pertemuan siklus ke 2 mencakup refleksi terhadap pelaksanaan pembelajaran yang telah dilaksanakan. Guru telah membimbing siswa dengan baik dalam mendengarkan dan menentukan ide pokok dengan Siswa terlihat sangat antusias dan berebut menjawab pertanyaan dari guru. Siswa perlu tetap dimotiVBsi agar dapat menulis dengan baik,teliti dalam menggunakan tanda baca yang benar. Metode anya jawab sebaiknya selalu dilakukan untuk membimbing siswa membangkitkan ide. Hasil refleksi tersebut dipakai sebagai abhan untuk menyusun perbaikan pembelajaran yang akan dilaksanakan pada pembelajaran berikutnya pada siklus selanjutnya. Hal-hal yang telah terlaksana dengan baik pada pertemuan sebelumnya dipertahankan sedangkan yang masih belum baik atau masih kurang akan dilaksanakan perbaikan pada prtemuan ke 2 .

\section{Pertemuan ke 2}

Pembelajaran tahap pramenulis. Pembelajaran diawali dengan salam, do'a, presensi kehadiran siswa dan mengkondisikan siswa agar mengikuti pembelajaran dengan baik. Kemudian guru melakukan kegiatan apersepsi dengan mengajukan beberapa pertanyaan pada. Guru memberikan informasi materi yang akan dipelajari siswa beserta tujuan mempelajari materi tersebut. Siswa memperhatikan penjelasan guru tentang menulis paragraf narasi. Siswa mendengarkan rekaman berita radio. Dalam membuat paragraf narasi siswa dibagi menjadi beberapa kelompok berpasangan, dalam hal ini guru langsung menentukan anggota kelompok berdasarkan teman satu bangku sehingga semakin terlihat mana siswa yang masih mengalami kesulitan dalam membuat paragraf narasi.

Tahap menulis. Siswa mengerjakan LKS sesuai dengan petunjuk yang tersedia menjadi kalimat dan mengembangkan kalimat menjadi paragraf narasi dengan baik, memperhatikan ejaan dan tanda baca yang benar. Tahap pascamenulis. Kegiatan yang dilakukan siswa dalam satu kelompok membaca kembali dan meneliti hasil tulisan dan memperbaiki tulisan jika dianggap masih kurang sempurna. Siswa menukarkan hasil pekerjaan pada kelompok bangku depan siswa untuk dinilai. Siswa diberikan kesempatan untuk membaca paragraf narasi yang telah dibuat oleh kelompok lain.

Kegiatan akhir pembelajaran, guru memberikan pemantapan materi pada siswa. Siswa menyimpulkan hasil pembelajaran yang dilalui. Siswa mengisi angket sebagai refleksi dan mengungkapkan kesulitan dan kesenangan dalam membuat paragraf narasi yang telah dilalui. Pemberian reword pada siswa. Pembelajaran diakhiri dengan do'a bersama. Hasil penilaian tulisan narasi siswa kelas VB SDN Kademangan 01 selama melakukan kegiatan pembelajaran adalah sebagai berikut diperoleh data bahwa siswa yang mendapatkan nilai di atas KKM adalah 29 siswa dan dinyatakan tuntas dalam menulis narasi sedangkan, 3 siswa mendapatkan nilai di bawah KKM sehingga belum dinyatakan tuntas dalam menulis. Siswa dinyatakan tuntas dalam pembelajaran keterampilan menulis jika mencapai nilai KKM yaitu 70. Apabila dipersentasekan siswa yang tuntas dalam menulis belajar adalah $87,8 \%$ sedangkan siswa belum tuntas 9,09\% dari jumlah siswa keseluruhan di kelas VB SDN Kademangan 01. Dapat disimpulkan, keterampilan menulis siswa kelas VB telah mencapai KKM, 29 siswa memiliki kemampuan menulis narasi di atas KKM. Hal tersebut menunjukkan bahwa pada pertemuan kedua siklus III siswa sudah tuntas dalam keterampilan menulis secara klasikal. Persentase ketuntasan siswa telah memperoleh nilai di atas KKM hanya $87,8 \%$ dari jumlah siswa. Nilai tersebut lebih besar dari persentase ketuntasan belajar yang harus dicapai yaitu $80 \%$. 
Novialita Angga Wiratama

\section{TEMUAN PENELITIAN}

Selama pelaksanaan penelitian menulis narasi menggunakan media rekaman berita radio di SDN Kademangan 01 kelas VB Kabupaten Blitar pada siklus I dan II, didapat beberapa temuan. Temuan yang didapatkan selama penelitian adalah Pendekatan yang digunakan guru dalam pembelajaran secara berkelompok dapat membantu siswa untuk saling berbagi informasi, berpikir bersama untuk memecahkan masalah dan saling berkomunikasi. Siswa masih kesulitan dalam membuat kalimat berdasarkan kata yang telah didata. Siswa tidak teliti dalam menggunakan tanda baca dan penempatan huruf kapital.

\section{PEMBAHASAN}

\section{Penerapan Media Rekaman Berita Radio Dapat Meningkatkan Keterampilan Menulis Narasi Siswa Kelas VB SDN Kademanagan 01}

Menulis termasuk aspek berbahasa yang dipelajari siswa. Menulis karangan narasi dilakukan siswa kelas V. Suparno (2007:1.11) menyatakan bahwa, narasi adalah ragam wacana yang menceritakan proses kejadian suatu peristiwa". Pembuatan tulisan narasi tidak bisa serta-merta tulisan langsung jadi dengan baik. Di dalam menulis diperlukan banyak praktik latihan menulis secara teratur sesuai dengan pendapat Tarigan, 1994: 34. Semakin sering berlatih menulis maka hasil tulisan siswa akan semakin baik. Menulis narasi melalui berbagai proses yang melibatkan sejumlah alat indera, serangkaian aktivitas dan melibatkan beberapa tahap dalam menulis. Untuk membantu siswa kelas $\mathrm{V}$ supaya dapat menulis diperlukan media yang tepat. Media rekaman berita radio belum pernah dimanfaatkan guru dalam pembelajaran sehingga dapat merangsang perhatian siswa. Hal ini sesuai dengan pendapat Miarso (dalam Heriawan dkk. 2003: 11.15) tentang fungsi media dalam pembelajaran.

Penerapan pembelajaran bahasa Indonesia dengan menggunakan media rekaman berita radio dapat meningkatkan hasil belajar siswa. Hal ini dapat terlihat adanya peningkatan hasil belajar siswa antara pratindakan, siklus I dan siklus II. Selama penelitian ini dilakukan, peneliti bertindak sebagai guru bermitra dengan guru kelas $\mathrm{V}$ sebagai observer untuk meningkatkan hasil belajar siswa kelas $\mathrm{V}$ SDNKademangan 01. Penggunaan media dalam pembelajaran memudahkan siswa memahami materi yang diajarkan guru. Hal ini sesuai fungsi media sebagai penyampai pesan dalam pembelajaran. Fungsi utama media yaitu mengefektifkan proses komunikasi dalam pembelajaran sehingga tercapai tujuan yang diinginkan sehingga timbul perubahan tingkah laku pada diri siswa (Sardiman, dkk 2010: 36).

Pada setiap siklus pembelajaran guru melakukan refleksi untuk mencapai tujuan pembelajaran yang optimal dalam menggunakan media pembelajaran. Pengalaman belajar yang dialami siswa selama pembelajaran banyak manfaatnya karena siswa mengalami sendiri apa yang dipelajari dan melalui proses pembel-ajaran yang runtut. Hal ini sesuai dengan penjelasan kerucut pengalaman Dale (dalam Munadi, 2010:19) bahwa siswa dapat dikatakan memiliki cara belajar yang berkualitas jika diperoleh melalui pengalaman langsung dan pengalaman tidak langsung. Semakin langsung objek yang dipelajari siswa, maka akan semakin konkrit yang diperoleh.

Berdasarkan paparan data hasil penelitian yang telah dilakukan pada siswa kelas $\mathrm{V}$ SDN Kademangan 01 pada pelajaran bahasa Indonesia keterampilan menulis dengan menggunakan media rekaman berita radio, dilaksanakan melalui tiga tahapan yaitu kegiata pramenulis,menulis dan pasca menulis. Sebelum melakukan pembelajaran guru mempersiapkan media pembelajaran berupa rekaman berita radio.

Kegiatan pembelajaran pada siklus I pertemuan pertama, guru membagi-siswa menjadi 5 kelompok, petemuan ke dua siswa dibagi secara kelompok berpasangan, peretuman pada siklus 2 siswa belajar secara mandir. Pada petemuan pertama dalam mendengarkan berita radio siswa masih membutuhkan $5 x$ putar untuk memahami isi dari berita,pada pertemuan ke 2 siswa sudah bia memahami isi berita 3x. Pada siklus ke 3 siswa sudah bisa memahami isi berita dalam 2x putar saja.

Pada penilaian proses pembelajaran, guru menilai aspek keberanian, kemandirian, dan ketepatan waktu dalam mengerjakan tugas para siswa. Hasil proses pembelajaran menulis pertemuan pertama siklus I, Tahap pramenulis. Selama kegiatan mendengarkan berita nampak beberapa siswa masih kesulitan dalam mencerna isi dari berita tersebut, sehingga perlu mengulasi memutar berita sebanyak $5 x$. Tahap menulis. Dalam tahap menulis siswa masih kesulitan dalam memulai menulis, kesulitan yang dialami oleh 
siswa diantaranya sulit membuat ide pokok yang akan dikembangkan.Oleh karena itu guru melalukan stimulus melalui bertanya apa isi dari berita kemudia siswa menjawab dengan menceritakan kejadian peristiwa. Setelah menulis peristiwa, siswa membuat ide pokok kemudian mengembagkan menjadi karangan narasi.. Siswa diberikan motiVBsi dan semangat berupa hadiah diakhir pembelajaran jika dapat dengan benar dalam menulis karangan narasi, selain itu guru juga memberikan bimbingan kepada setiap kelompok. Ada beberapa siswa dalam kelompok yang hanya bermain-main.

Dalam mengembangkan ide pokok siswa tidak mengalami kesulitan namun kurang teliti dalam menggunakan huruf kapital. Dalam membuat kalimat hanya dilakukan oleh satu atau dua orang dalam satu kelompok, siswa masih menggantungkan diri pada teman yang dianggap pandai dan mampu.

Tahap pascamenulis. Siswa dalam satu kelompok membaca dan meneliti kembali hasil tulisan narasi yang telah dibuat sebelum ditukar untuk dinilai oleh teman. Siswa membaca dan meneliti kembali pekerjaan mereka dengan bersungguh-sungguh, meskipun ada beberapa siswa yang bermain sendiri di dalam satu kelompok.

Pembelajaran siklus 2 tahap pramenulis guru memberikan informasi materi yang akan dipelajari siswa beserta tujuan mempelajari materi tersebut. Siswa memperhatikan penjelasan guru tentang menulis paragraf narasi. Siswa mendengarkan rekaman berita radio. Dalam membuat paragraf narasi siswa dibagi menjadi beberapa kelompok berpasangan, dalam hal ini guru langsung menentukan anggota kelompok berdasarkan teman satu bangku sehingga semakin terlihat mana siswa yang masih mengalami kesulitan dalam membuat paragraf narasi.

Tahap menulis. Siswa mengerjakan LKS sesuai dengan petunjuk yang tersedia menjadi kalimat dan mengembangkan kalimat menjadi paragraf narasi dengan baik, memperhatikan ejaan dan tanda baca yang benar. Tahap pascamenulis. Kegiatan yang dilakukan siswa membaca kembali dan meneliti hasil tulisan dan memperbaiki tulisan jika dianggap masih kurang sempurna. Siswa menukarkan hasil pekerjaan pada kelompok bangku depan siswa untuk dinilai. Siswa diberikan kesempatan untuk membaca paragraf narasi yang telah dibuat oleh siswa lain.

\section{Peningkatan Keterampilan Menulis Melalui Menyimak Rekaman Berita Radio Siswa Kelas V SDN Kademangan 01 Kabupaten Blitar}

Hasil penilaian proses siswa pada saat pembelajaran bahasa Indonesia keterampilan menulis melalui menyimak rekaman berita radio mengalami peningkatan. Hal ini dapat dilihat dari perbandingan aktivitas siswa pada pratin-dakan dan sesudah diberi tindakan. Pada pratindakan tidak tampak aktivitas siswa karena selama pembelajaran siswa hanya mendengarkan penjelasan dari guru, mengerjakan tugas dari guru, mengumpulkan tugas, siswa tidak mengkomuni-kasikan hasil pekerjaanya di depan kelas sehingga aspek dalam penilaian proses tidak terlihat.

Hasil pengamatan proses belajar siswa pada siklus I dan II dengan indikator keberanian, kemandirian dan ketepatan siswa terlihat serius dalam menyimak rekaman berita radio namun masih bingung dalam menganalisis isi berita yang diputarkan. Masih terdapat siswa yang ragu dalam mengkomunikasi-kan hasil pekerjaannya dan ada beberapa siswa yang terlihat kurang aktif dalam menanggapi hasil pekerjaan teman. Pada pelaksanaan pertemuan kedua siswa lebih serius dalam mengikuti pembelajaran dan menyimak rekaman berita radio yang diputarkan guru. Siswa lebih aktif dalam melaporkan hasil pekerjaannya di depan kelas dan siswa yang lain sudah berani mengemukakan tanggapan atas hasil pekerjaan temannya dibandingkan dengan pertemuan sebelumnya. Dari keaktifan siswa tersebut maka berdampak pada hasil pembelajaran siswa. Peningkatan aktifitas siswa dalam pelajaran bahasa Indonesia melalui menyimak rekaman berita radio tersebut sesuai dengan pendapat Anitah. Jenis media yang dapat digunakan dalam pembelajaran bahasa Indonesia untuk meningkatkan keterampil-an menulis adalah dengan menggunakan alat rekam seperti casset tape recorder Anitah, (2010: 39).

Hasil analisis data dari pratindakan sampai akhir siklus, diperoleh hasil sebagai berikut. Jumlas siswa kelas VB adalah 33 anak. Siswa dikatakan tuntas dalam keterampilan menulis narasi jika mencapai nilai sama dengan KKM. Siswa dinyatakan tuntas secara klasikal jika mencapai $80 \%$ dari jumlah siswa 
Novialita Angga Wiratama

yang tuntas menulis paragraf narasi. Pada pratindakan terdapat 22 siswa yang belum tuntas dalam menulis narasi dengan rata-rata kelas hanya 67.

Pada tindakan pertama siklus satu terdapat 12 siswa yang belum tuntas dan 21 siswa tuntas dalam menulis narasi dengan buah pisang sebagai objek yang dinarasikan. Apabila dipersentasekan siswa yang tuntas dalam menulis belajar adalah $63,6 \%$ sedangkan siswa belum tuntas $36,6 \%$ dari jumlah siswa keseluruhan di kelas. Sedangkan hasil dari pertemuak kedua 23 siswa dan dinyatakan tuntas dalam menulis narasi sedangkan, 10 siswa mendapatkan nilai di bawah KKM sehingga belum dinyatakan tuntas dalam menulis. Siswa dinyatakan tuntas dalam pembelajaran keterampilan menulis jika mencapai nilai KKM yaitu 70. Apabila dipersentasekan siswa yang tuntas dalam menulis belajar adalah 69,6\%sedangkan siswa belum tuntas $30,3 \%$ dari jumlah siswa keseluruhan di kelas $\mathrm{V}$.

Hasil belajar siswa kelas VB pada siklus ke dua pertemuan pertama siswa yang mendapatkan nilai di atas KKM adalah 25.8 siswa mendapatkan nilai di bawah KKM sehingga belum dinyatakan tuntas dalam menulis. Apabila dipersentasekan jumlah siswa tuntas dalam menulis belajar adalah 75,7\%, siswa belum tuntas $24,2 \%$ dari jumlah siswa keseluruhan di kelas.Nilai tersebut lebih kecil dari persentase ketuntasan belajar yang harus dicapai yaitu $80 \%$. Pada pertemuan ke dua 29 siswa dan dinyatakan tuntas dalam menulis narasi sedangkan, 3 siswa mendapatkan nilai di bawah KKM sehingga belum dinyatakan tuntas dalam menulis. Siswa dinyatakan tuntas dalam pembelajaran keterampilan menulis jika mencapai nilai KKM yaitu 70. Apabila dipersentasekan siswa yang tuntas dalam menulis belajar adalah $87,8 \%$ sedangkan siswa belum tuntas 9,09\% dari jumlah siswa keseluruhan di kelas VB SDN Kademangan 01. Dapat disimpulkan, keterampilan menulis siswa kelas VB telah mencapai KKM, 29 siswa memiliki kemampuan menulis narasi di atas KKM. Hal tersebut menunjukkan bahwa pada pertemuan kedua siklus III siswa sudah tuntas dalam keterampilan menulis secara klasikal. Persentase ketuntasan siswa telah memperoleh nilai di atas KKM hanya 87,8 \% dari jumlah siswa. Nilai tersebut lebih besar dari persentase ketuntasan belajar yang harus dicapai yaitu $80 \%$.

\section{PENUTUP \\ Kesimpulan}

Penerapan media rekaman berita radio dalam meningkatkan keterampilan menulis narasi siswa kelas VB dilakukan dengan beberapa langkah pembelajaran yaitu persiapan, pelaksanaan, dan langkah tindak lanjut. Pada tahap persiapan guru menyiapkan media rekaman berita radio untuk diputarkan pada siswa di dalam kelas. Langkah menulis narasi dilakukan melalui tiga tahap yaitu tahap pramenulis,menulis dan pasca menulis. Langkah penindaklanjutan siswa melaporkan hasil tulisannya dan menanggapi hasil pekerjaan teman.

Digunakannya media rekaman berita radio dalam pembelajaran bahasa Indonesia terbukti dapat meningkatkan aktifitas dan hasil belajar siswa dalam menulis karangan narasi. Hal ini dapat dilihat dari nilai hasil yang diperoleh dari proses menulis narasi. Sehingga dapat disimpulkan bahwa penerapan pembelajaran bahasa Indonesia dengan menggunakan media rekaman berita radio dapat meningkatkan kemampuan menulis narasi siswa kelas VB.

\section{Saran}

Dalam pembelajaran bahasa Indonesia keterampilan menulis narasi, penggunaan media rekaman berita radio dapat menarik minat belajar siswa sehingga siswa akan tertarik terfokus menyimak materi yang berita yang diputarkan oleh guru, siswa merasa tidak bosan dengan fariasi media yang digunakan sehingga tetap aktif dalam pembelajaran. Hendaknya guru menggunakan media rekaman berita radio dalam menerapkan pembelajaran yang efektif dan menyenangkan bagi siswa sehingga siswa lebih aktif dalam belajar. Perlu adanya perlakuan khusus bagi 4 siswa di kelas V SDN Kademangan 01 yang belum tuntas hasil belajar dalam pembelajaran bahasa Indonesia Keterampilan menulis, seperti perhatian lebih dari guru terhadap proses belajarnya dan pemberian motiVBsi untuk belajar lebih giat. 


\section{DAFTAR RUJ UKAN}

Anitah, Sri. 2010. Media pembelajaran. Surakarta:Yuma Pustaka.

Arikunto, S. 2002. Prosedur Penelitian Suatu Pendekatan Praktek, Edisi Revisi V. Jakarta: Rineka Cipta.

Heriawan Asep Herry, dkk. 2003. Pengembangan Kurikulum dan Pembelajaran. Jakarta: Universitas Terbuka.

Mulyati, Y. 2010. Bahasa Indonesia. Jakarta. Universitas Terbuka.

Munadi,Yudhi. 2010. Media Pembelajaran Sebuah Pendekatan Baru. Jakarta: Gaung Persada Press.

Sardiman. 1994. Interaksi dan MotiVBsi Belajar Mengajar. Jakarta: Raja Grafindo Persada.

Suparno. 2007. Keterampilan Dasar Menulis. Jakarta: Universitas Terbuka

Tarigan, Henry Guntur. 1994. Menulis sebagai Suatu Keterampilan Berbahasa. Bandung: Angkasa.

Wibawa dan Mukti. 1991. Media Pengajaran. Jakarta: Dirjendikti. 